\title{
The Management Mode Optimization for Pioneer Park of Wuhan University of Technology
}

\author{
Haochuan Lu \\ School of Management, Wuhan University of Technology, Wuhan, Hubei Province, 430070, China. \\ 645154814@qq.com
}

Keywords: Management mode; Pioneer park; Operating mechanism

\begin{abstract}
Along with the social employment pressure increasing, more and more college students choose business. Government and schools support entrepreneurship for college students more and more. In such form, college students Pioneer Park became the state that supports the best platform for carving. However, due to the pioneer park construction in our country starts late, pioneer park management system is not perfect. The operating effect of many college students pioneer park is not good. Based on the management mode of college students pioneering park as the research subject, as a case study of Wuhan university of technology business incubator, pioneer park for college students has carried on the comprehensive analysis; After the field survey and the interview, combining with theoretical analysis, points out the lacking of pioneer park of Wuhan university of technology in the organizational structure, operation mechanism. And putting forward the optimization advice, to be able to provide certain reference and basis for the construction of the college students pioneer park.
\end{abstract}

\section{Introduction}

From the point of foreign scholars study, college students Pioneer Park will stimulate the development of local economy and it is the place that can create wealth and opportunities [1]. The establishment of the college students pioneer park support for start-up companies which is an effective mechanism for a kind of understanding that is based on the college students pioneer park that has many Shared resources [3]. Such as office space, water and electricity, infrastructure, government's financial support and the injection of risk investment fund [2]. The ultimate aim is to profit, and college students pioneering park will gradually by knowledge and professional skills leading to for the commercial market leading [4]. From the domestic scholars study, college students pioneer park construction promote employment as the leading direction actually [5,6]. Universities create college students Pioneer Park that is also to ease the employment pressure as the main target [7]. College students' entrepreneurial culture is a relatively independent function and position of a kind of education idea [8].

In terms of the development of pioneering park itself, scholars believe that college should adhere to the entrepreneurial environment model and simulation environment model combined and puts forward two dominant form of pioneer park construction including the government leading and market pulling $[5,10]$. On this basis, some scholars put forward three pioneer park management patterns including the school arranged model, collaborative between colleges and autonomous management to adapt to different period the development of college students pioneering park [9]. Although in recent years, the development of college students Pioneer Park is very rapidly, there are problems such as single creation team, insufficient in scientific and technological content and inadequate hardware and software [11].

\section{Method}

Based on the management mode of college students pioneering park, as the research object, reveals the definition and characteristics of college students pioneering park including management mode, operation mechanism and guarantee conditions. For an example of pioneer park of Wuhan 
university of technology, the organizational structure and operation mechanism has carried on the comprehensive analysis; After the field survey and the interview, combining with theoretical analysis, points out that lacking of pioneer park of Wuhan university of technology in organizational structure, and the operation mechanism and puts forward the optimization advice.

This paper uses methods of the combination of theoretical research and field survey research. On the one hand, through the consult literature material, understand management model of pioneer park. On the other hand, through the personnel interview, understand the operation of the business model in all aspects of business incubator.

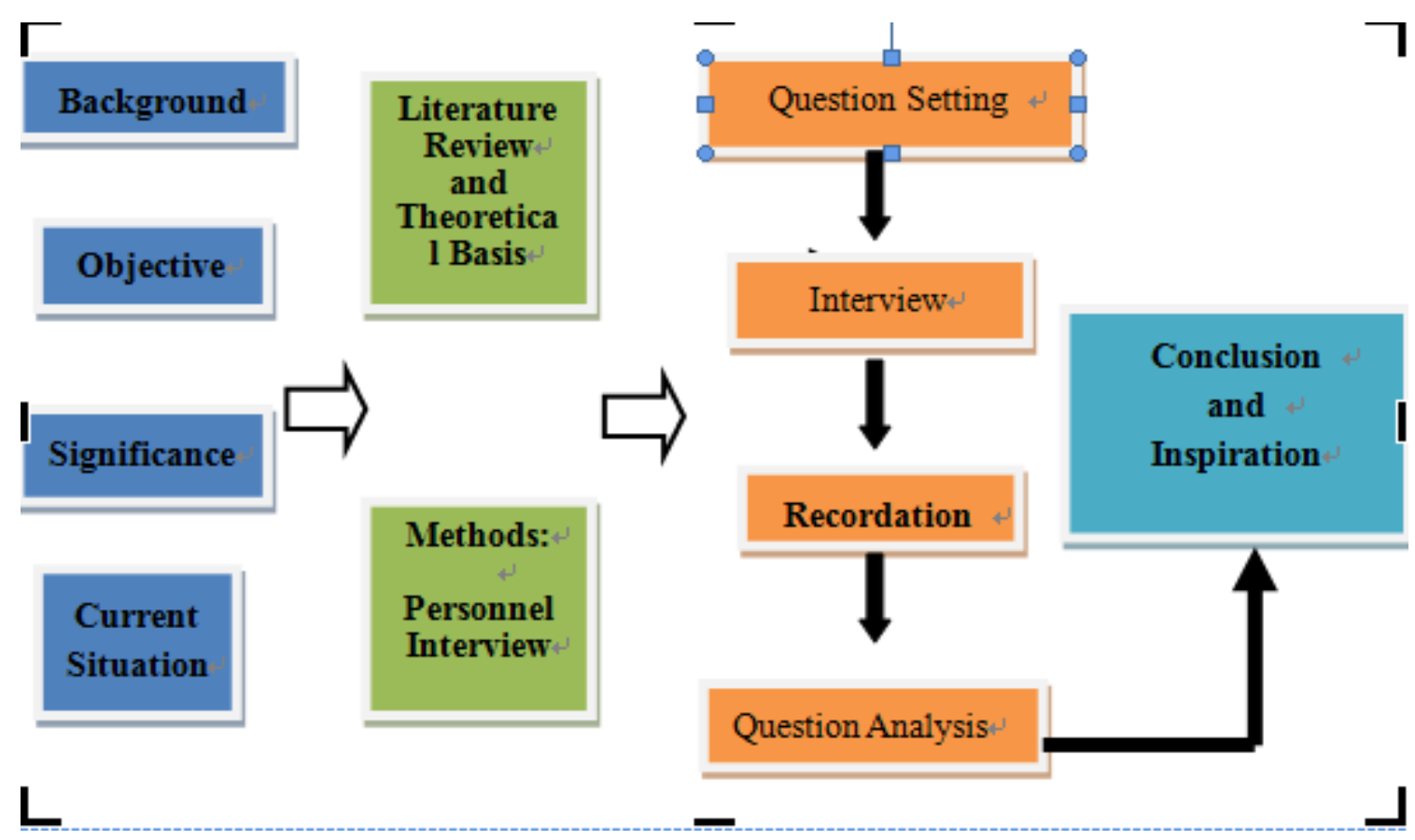

Figure 1. The technology roadmap

\section{Optimization}

Optimization for the organizational structure. Entrepreneurship training has a vital role to promote entrepreneurial leadership, enhance professional skills of entrepreneurs and entrepreneurial team spirit. So the suggestion is that the park should set up a business start-up training team. The team is composed by school teachers and campus business people together, responsible for making business park enterprise training, including training needs analysis, the early stage of the training plan, training the guest invited, training, equipment purchase, training venue layout, training results investigation and feedback. All this work finished by entrepreneurship training team, and entrepreneurship training team also shoulder the pioneer park development conforms to the development of entrepreneurship training system, from starting to improve to the development of a comprehensive range of entrepreneurship training services for pioneer park enterprises. In addition, in the entrepreneurship training, the team is also noting the following two questions.

First, training team members determine that whether the training team with high efficiency and high quality finish training work ability. So on personnel configuration, the pioneer park should not only have wide connections and experienced teachers, also want to have young students who have strong execution; The pioneer park should not only have people who are mind exquisite and considerate, but also have people who are consumedly and highly effective. Make the member can complement each other and the work will get twice the result with half the effort.

Second, although training team sheet is set out, it is still responsible for the team. Training team is still led by the office. Working content is more focused and the working direction is clearer. 
Optimization for Operation Mechanism. Pioneer Park in early-stage companies, because its management situation is not stable and the management efficiency is not high, the general guarantee company or business capital is not willing to put money into companies like pioneer park. The bank is also interested in the large companies that have stable operating performance. Moreover, because of the difference of operating conditions and credibility of company in Pioneer Park which will also bring the sense of insecurity to the bank? So, the pioneer park can form guarantee agencies, including evaluation experts, providing guarantee services for better market prospects pioneer park enterprise, to reduce the risk of commercial bank loans. Pioneer Park can choose a variety of ways of cooperation with risk investment institutions. Risk investment agencies and Pioneer Park could simply be business cooperation. But management level is not to cross. The company out of the park can also set up an investment institutions with Pioneer Park, to venture into campus startups [13]. Pioneer park can choose to go deep into the inside or only external cooperation. Variety of ways cooperation can promote the Pioneer Park and venture capital closer together and achieve mutual benefits and win-win results.

Enterprises in the pioneer park cannot become greenhouse flowers. Even under the support of policy, they also face a challenge to maintain the life of the enterprise vitality. So setting up competition mechanism, according to the specific conditions of different enterprises, enterprises targeted for operating profit targets,. For enterprises who cannot reach regulation index and development potential, Pioneer Park can enforce it exit to keep the enterprise quality superior in pioneer park of Wuhan university of technology.

Pioneer Park of Wuhan University of technology is to help college students in Wuhan entrepreneurial success. Enterprise that develop to a mature period will have to leave college students pioneer park for letting the fresh blood into and such mechanisms allow pioneer park to maintain liquidity and vitality. For the "graduation" of garden enterprise, pioneer park need to establish a corresponding graduation mechanism and set up a corresponding "graduation" data, such as operating profits and market competitiveness. Pioneer Park gives an integrated evaluation of these indicators to determine whether garden enterprise has the qualification of "graduation". For the enterprises that have graduation qualification, Pioneer Park can reward it appropriately and make enterprises face challenge in better [14].

For the company that has good development prospects in Entrepreneurship Park, Pioneer Park can provide the enterprise in its early stage of development with funds, consulting and technology services. With the money in the business or service ,as their holdings of equity, holding these sound development of enterprises, after the original shares of enterprises growing even listing in the gardens, pioneer park can get considerable income through the stock right transfer or participating dividend [15].

\section{Significance}

The theoretical significance of this paper lies in: (1) For college students pioneer park management pattern research, enrich the theory of pioneer park management perspective and research issues. (2) This paper extends application field of the comparison research, case study group, interview method and other methods, and the theory of entrepreneurial economy and business management.

The practical significance of this paper lies in: (1) this paper can provide theoretical reference for pioneer park management and facilitate more scientific and reasonable government formulated to support policy. (2) This paper perfects the organizational structure of the Wuhan University of Technology pioneer park and optimizes the pioneer park operation mechanism. This paper help schools manage pioneer park more scientific and cultivate the innovative entrepreneurial talent. (3) This paper help college students to create a good business conditions and the environment that enables the students to manage Pioneer Park better and achieve self-worth. 


\section{Reference}

[1] H. Amirahmadi, G. Saff, Science parks: a critical assessment, Journal of Planning Literature, 1993, 8(2):107-123.

[2] Y.L. Bakouros, D.C. Mardas and N.C. Varsakelis, Science Park, a high tech fantasy: an analysis of the science parks of Greece. Technovation, 2002, 22(2): 123-128.

[3] S.M. Hackett, D.M. Dilts, A systematic review of business incubation research, The Journal of Technology Transfer, 2004, 29(1): 55-82.

[4] F. Hansson, K. Husted and J. Vestergaard, Second generation science parks: from structural holes jockeys to social capital catalysts of the knowledge society Technovation, 2005, 25 (9):1039-1049.

[5] D.J. Zhou. Talk about college students pioneer park construction [J]. Economic research Tribune, 2011, (27): 304-305 (In Chinese).

[6] $\mathrm{H}$. Hu. Combined with their own advantages continuously explore the power of innovation for the from all walks of life make college students pioneer park construction [J]. Journal of exploring education, 2015, (1): 22 and 23 (In Chinese).

[7] X.J. Yan. Based on B/S structure of college students Pioneer Park of science and technology management system design and safety analysis [J]. Science and technology innovation and productivity, 2013, (229): 55 to 59 (In Chinese).

[8] Q.S. Wang. Huang Yong. Foreign college students' entrepreneurship education enlightenment and reference $[\mathrm{J}]$. Journal of empirical research, 2012, (10): 23-27 (In Chinese).

[9] L.J. Zhou and D.H. Li. The construction of college students pioneering park positioning and strategy [J]. China's school education, 2013, (10): 6-7 (In Chinese).

[10]L. Huang. "Congress" in higher vocational colleges students pioneer park since research [J] modern trade industry, 2012, (9): 139-140 (In Chinese)

[11]J. Li and. S.Q. Li. College students pioneer park existing problem and countermeasure research [J] Xuzhou vocational college journal, 2011 (1) : 52-53 (In Chinese).

[12]H.Y. Hu , S.F. Duan, X.Y. Pei and S.Y. Kang. In our country present situation, characteristics and trend of development of the incubator $[\mathrm{J}]$. Science and technology progress and Countermeasures, 2008, (10): 2008-193. (In Chinese).

[13]L. Hao and S.X. Lei. Theoretical analysis of the operation mechanism of agricultural Pioneer park in China [J]. Science and technology progress and countermeasures, 2009, (17): 19-24 (In Chinese).

[14]Y. Lin. Analyses the construction of college students the importance of business incubators [J]. Journal of ancient, 2013 (16): 134-135. (In Chinese).

[15]X.F. Huang. Entrepreneurs to cognitive based on empirical study of elements of the environment [J]. Journal of enterprise economy, 2009 (2): 77-78 (In Chinese). 